\title{
Humane Concern in the Ideological and Political Education of College Students and Its Realization Path*
}

\author{
Yanqing Zeng \\ Xi'an FanYi University \\ Xi'an, China
}

\begin{abstract}
Under the guidance of the Party, the issue of ideological and political education for college students has drawn more and more attention. And the corresponding mental health education has gradually become the focus of attention of colleges and universities. The ideological and political education of college students is not only related to the overall development of the students, but also has an important influence on social harmony. Therefore, it is necessary to choose appropriate methods to continuously strengthen the level of mental health education for college students. The article will explore the realization of humane concern in the ideological and political education of college students in four aspects. First, the status quo of psychological health of college students is elaborated. It includes common mental health problems and performance of college students. Secondly, the foundation of ideological and political education for college students is established. It analyzes the influencing factors, including education, family and social environment. This will be used as the basis for follow-up research. Third, it elaborates the significance of ideological and political education for college students based on humane concern. Finally, it puts forward the way to realize college students' ideological and political education on the basis of humanistic concerns.
\end{abstract}

Keywords-college students; ideological and political education; humane concern

\section{INTRODUCTION}

In recent years, it is in the transformation stage of China's education. In this important period, many issues that have not been paid attention to in the past have been included in the key content of modern education. Among them, the issue of ideological and political education for college students is one of them. In the new era, our party has put forward higher requirements for the ideological and political education of modern college students. It is necessary for colleges and universities to actively explore new strategies for the ideological and political education of college students under

*This article is the research achievement of Shaanxi Provincial Social Science Fund Project - "Humane Concern and Psychological Consultation in the Ideological and Political Education of College Students in Shaanxi Province" (Project No. 2014M04). This article is the research result of 2018 annual key academic exchange and science and technology service project of Xi'an Science and Technology Association - "post-90s college students' mental health education activities". the guidance of the party. In the process of modern university students' ideological and political education, it is worth noting that the education activities need to highlight humane concern, which is of great significance for establishing a sound personality, promoting the development of quality education, and promoting social harmony among college students.

\section{College Students' Mental Health}

According to relevant statistical results, the prevalence of mental health problems among undergraduates is increasing year by year, which has a negative impact on the overall quality of college students. From the perspective of the psychological health problems of college students, the more common ones include psychological paranoia, interpersonal difficulties, and low self-esteem.[1] For example, some students in a certain university would refuse to participate in any public activity organized by the school or the class. In the class, he always be alone. He does not contact with other people. After we have knew more about the student, we could discover that the student has a certain amount of social fear. He refuses to contact with others. This situation is a difficult problem of interpersonal communication. Such problems are more common among college students. However, the situation of the student is obviously more serious. This is also related to the lack of mental health education and the family environment.

\section{ANALYSIS ON THE INFLUENCING FACTORS OF COLlEge STUdENTS' IDEOLOGICAL AND POLITICAL EDUCATION}

\section{A. Educational Factor}

Under the influence of the traditional education concept and the domestic environment for exam-oriented education, there are still many drawbacks in China's higher education. For example, it puts the focus of education on professional education blindly, and lacks of attention to students' overall quality education. This is also the main reason leading to the psychological health problems of some college students [2]. The disadvantages of the exam-oriented education system have not been solved for a long time. The education of colleges and universities will not face the pressure of 
enrolment rate. The traditional teaching concept under the exam-oriented education system still affects the development of higher education. In the modern college education model, the universal colleges and universities take student's academic record of professional course as the main criterion for student evaluation. This leads to the students' long-term monotonous professional learning status. And the pressure caused by the modern employment form would make some students have poor psychological health conditions.

\section{B. Family Factor}

The family environment plays an important role in the development of a person's mental health. The parents' education level, the way they treat their children, family relations, etc., all belong to the major factors causing the mental health of college students. Judging from the situation of domestic family education, the majority of students' family environment is not conducive to the students' mental health. For example, some parents adopt rude education for their children, and lack communication with their children in daily life. Once the children have inappropriate behavior, they would take the reprimand or maltreatment. And the child wouldn't communicate with the parents after encountering problems in the school. In the long run, it will lead to mental health problems [3]. College students have a series of difficulties in learning and living as well as employment. If they do not receive parental encouragement after experiencing setbacks, they can easily have the feelings of aggrievedness and depression. If the parents don't pay attention to this kind of mental problem, it can be further developed into depression, which greatly affects the healthy growth of students.

\section{Social Environment Factor}

The development of the information age has played an extremely important role in promoting the rapid development of society. However, the Internet is a double-edged sword. While promoting social productivity, it also leads to modern college students accessing various bad information through the Internet [ 4]. There are still some omissions in the network-based supervision system, which leads to a variety of dirty and violent information in the online platform. At the same time, some negative so-called individualized behaviors have also influenced contemporary college students. For example, on various popular online broadcast platforms, college students have joined the live streaming after seeing the quick profit acquisition methods of many anchors. And then, it would affect their professional learning. Some students have chosen to be anchor rather than a students. Such bad ideas will directly affect the values of university students.

\section{SignificAnce of COLLEGE StUdents' IdEOLOGICAL AND POLITICAL EdUCATION BASED ON HUMANE CARE}

\section{A. To Promote the Overall Development of College Students}

Comprehensive quality discovery is a new requirement put forward by the education industry in the new era, and it is also the basic principle of modern colleges and universities in cultivating qualified socialist successors. The purpose of quality education is to train college students in an all-round way. They can become comprehensive talents that meet the needs of social development. This will contribute to the future career development of students and the rapid development of society [5]. This comprehensive development refers to the sustainable development of students in all aspects. The higher quality covers many aspects such as moral quality, ability quality and psychological quality. Among them, mental health education has realized the key content of education reform in the new period. Psychological quality plays a basic role in the quality of talents, and has an impact on the development of all qualities. Therefore, we must adhere to the psychological counseling of college students. It promotes the establishment of correct values and outlook on life. And the students will serve the society better in the future [6].

\section{B. To Safeguard Social Stability and Unity}

A healthy psychology can ensure that college students rationally analyze the current situation, face various setbacks with optimism, and overcome various difficulties and have healthy growth. The psychological health education based on humane concern is an important channel to protect the psychological health of college students [7]. Because of the premature exposure to social unhealthy habits, modern college students find it difficult to identify bad information. As a result, they may be exposed to all kinds of bad behaviors in the society. And even, they would distort themselves in the values. This is not good for the harmony among students and the harmonious development of society. By giving mental health education to college students and expressing humane concern in the process, it can promote the solution of inner convictions, promote inner harmony, eliminate psychological barriers of students, and control illegal acts that are not conducive to social harmony based on psychological problems.

\section{To Promote the Development of the Socialist Cause}

The party has further emphasized the humane concern and psychological counseling in modern university students' ideological and political education. This is an important manifestation of the advanced nature of the CPC's work [8]. Paying attention to the mental health of college students represents the party's emphasis on education. And it also shows the party's innovative spirit and sense of innovation in education. Education is the main means to develop a person's potential. Through the development of mental health education, students can form good psychological quality. And it can guide the students to establish correct values. Then, they can actively participate in the construction of socialism with Chinese characteristics in the future. In addition, the healthy mentality of college students is more conducive to the development of their own potential. It can increase their self-confidence, and assist them in understanding themselves more objectively. They can make correct positioning. And the role can be successfully transformed. The students can consciously assume the mission of building socialism with Chinese characteristics. 


\section{THE WAY To REALIZE IDEOLOGICAL AND POLITICAL EdUCATION OF COLLEGE STUdENTS BASED ON HUMANE CONCERN}

\section{A. Eliminating the Original Misunderstanding of Mental Health Education}

The issues concerning mental health of college students have increasingly drawn attention from colleges and universities in recent years. Many colleges have established mental health consultation platforms for college students. However, from the current state of implementation of mental health education in various universities in China, there is a serious imbalance in the development of various tasks. [9]. For example, some student management departments of colleges and universities have one-sided understanding of the importance of mental health education of college students. They have not been able to highlight the general status of mental health education in student management activities. They unilaterally believe that college students have independent adjustment ability to solve psychological problems. Only in the process of student consultation will the questions raised by the students be answered. And this kind of mental health education obviously cannot achieve the ideal effect. In view of this situation, the colleges and universities must make adjustments to the current misunderstandings of mental health education. For example, the colleges and universities must objectively recognize the significance of mental health education under the guidance of the party. And they should regard it as a key project for student management. The original passive mental health education was transformed into active form. The colleges and universities should understand students' common mental health problems and causes, and actively improve students' psychological problems to promote their healthy growth.

\section{B. Paying Attention to Humanistic Courses and Campus Culture Construction}

Classrooms are the main learning places for students. If the colleges and universities can integrate humane concern and psychological counseling into curriculum education, the mental health education certainly exert greater value. In the course design, the proportion of humanities classrooms should be appropriately increased. It can enrich the content of students' learning. At the same time, it can also help cultivate the students' humanistic qualities and form an optimistic attitude.[10] There are obvious differences in the cultivation of students' humanistic spirits and other qualities. It should choose a more targeted approach. In the classroom and daily management, the colleges and universities should infiltrate humane concern. And the colleges and universities should guide the students through various channels. In the cultivation of humanistic literacy, the problem that needs attention is to permeate the humanistic education throughout the entire university education process. It could prompt students to establish correct values and a sound personality in the process of understanding more traditional cultures and Chinese virtues. In addition, colleges and universities also need to pay attention to the construction of campus culture. Campus culture can objectively show the style of the school. It belongs to the soft environment of campus. And it has certain influences on students. It can provide a good environment for students by means of campus culture construction. It is good for mental health of the students.

\section{Constructing College Students' Mental Health Files}

The construction of college students' mental health files can fully reflect the humane concern of the management of college students. The students would feel the attention of the school to their overall development. The construction of student mental health files needs to be established on a scientifically regulated scale to describe and reflect the students' intelligence and personality as well as learning adaptability. The required functions are to assess the students' mental health status and their future career potential. It can make the analysis from multiple aspects. And then, it would get a more complete data of students' health. The student mental health file can serve as a major reference for student management workers. It can promote more targeted psychological health education programs for college students. Then, it would maximize the value of mental health education.

\section{Creating Good Group Psychology}

College students belong to high-quality groups. And the psychological pressure and internal conflicts they face are more obvious. These pressures include academic difficulties, employment problems, and difficulties in interpersonal communication, self-cognition, and so on. The students who cannot resolve inner pressures often have various psychological problems such as confusion and autism. In view of this situation, the students are required to feel humane concern through various means in the mental health education activities based on humane concern. These activities would create good group psychology. And they would also strengthen the cohesion among students and the sense of belonging to the school. The construction of group psychology can enhance the attractiveness of groups to students. With the promotion of the common goals of groups, it can give guidance to group activities. At the same time, the colleges and universities must actively encourage and guide the students to participate in the development of various mental health education activities, and promote the friendship between the students and the care from the school. This plays an important role in training students to establish a sound personality.

\section{E. Assisting College Students in Shaping Healthy Personality}

In the process of mental health education, it should pay attention to the students' healthy psychology. Also, it needs to pay attention to the formation of sound personality. In the process of assisting them in shaping a healthy personality, the following strategies can be selected. First, the colleges and universities should guide college students to make correct positioning. At this stage, some students are not able to objectively understand themselves and make correct positioning. There may be situations such as being overbearing. It is necessary to guide students to correctly conduct self-analysis, find their own advantages and 
disadvantages. With taking this as the basis, the students could make self-positioning. Second, the colleges and universities should strengthen the education of ideals and beliefs. In the modern economic society, people's material desires are stronger. College students may experience psychological imbalances in the face of various temptations. They may have an unhealthy consumption concept. For example, campus credit has developed rapidly in recent years. And it has led students to have consumption in advance. As a result, many students would face greater economic problems. For this purpose, the colleges and universities must strengthen the education of ideals and beliefs to promote students to form correct values. Then, they can resist external material temptation.

\section{CONCLUSION}

This article takes the prevalent mental health problems of modern college students as the foundation. And it analyzes the realization path of humane concern in health education. From the perspective of the importance of the development of mental health education, this work is of great significance for students' all-round development and social harmony. The humane concern of the colleges and universities are mainly reflected in guiding students to establish correct and positive values and outlook on life. Combining the practice of mental health education in colleges and universities in recent years, it is not ideal. The author believes that colleges and universities must objectively recognize the importance of mental health education and incorporate it into the management of students. The colleges and universities would continuously explore advanced and feasible implementation path of health education. And then, the colleges and universities would guide college students better.

\section{REFERENCES}

[1] Yang Hai, Xie Dan. Analysis on the Optimized Path to Hidden Curriculum of University Students' Mental Health[J]. School Party Building and Ideological Education, 2018, 08(5):58. 杨海, 谢丹.浅 析大学生心理健康隐性课程的优化路径 [J]. 学校党建与思想教 育，2018，08(5):58

[2] Li Weilan. Analysis on Mental Health Education of Contemporary College Students and application - Comment on "Students' Mental Health Education" [J]. Chinese Journal of Education, 2017, 09 (1): 36. 李伟兰. 当代大学生心理健康教育及应用分析一一评《学生心理 健康教育》[J].中国教育学刊, 2017, 09(1):36.

[3] Li Kuigang. Exploration of College Students' Mental Health Education in Network Environment [J]. Journal of Chengdu University of Chinese Medicine (Education and Science edition), 2010,(1):100-101. 李奎刚.网络环境下大学生心理健康教育探索[J]. 成都中医药大学学报(教育科学版), 2017, 04(1):100-101

[4] Lian Weili. Exploration of Mental Health Problems with the Times - A Review of College Students' Mental Health Education[J]. Chinese Journal of Education, 2017, 07(5): 04. 连伟利.与时俱进的 心理问题探索——评《大学生心理健康教育》 [J]. 中国教育学 刊, 2017, 07(5):04.

[5] Wang Yunting. Analysis on English Teaching Methods of Mental Health Education of College Students [J]. Textile Printing and Dying Additive, 2017, 08(s1):47. 王芸婷. 浅析大学生心理健康教育的英 语教学法[J].印染助剂, 2017, 08(s1):47.

[6] Wei Wei, Wu Baojie, Wang Chen. Realization Path of Undergraduate Mental Health Education Course Based on Intersubjectivity Theory [J]. Chinese Journal of Medical Education Research, 2017, 16(2):141-
144. 韦炜，吴宝捷，王琛.基于主体间性理论的大学生心理健康 教育课实现途径[J].中华医学教育探索杂志, 2017, 16(2):141-144.

[7] Xiong Juanmei. Analysis of Undergraduates' Mental Health Education in the Network Environment - A Review on the Improvement of Undergraduates' Internet Mental Health Quality [J] Chinese Journal of Education, 2017, 09(3):29. 熊娟梅.网络环境下 大学生心理健康教育探析- - 评《大学生网络心理健康素质提升 研究》[J].中国教育学刊, 2017, 09(3):29.

[8] Li Dong. Research on Humane Concern and Mental Health Education of University Students [J]. Business Conditions, 2016, 04(46). 李冬. 人文关怀与大学生心理健康教育研究 [J]. 商情, 2016, 04(46).

[9] Wu Hong. Research on the Theory and Practice of College Students' Mental Health - Comment on "College Students' Mental Health Education: Experience, Cognition and Training" [J]. China Higher Education Research, 2018, 08 (1): 47. 吴红.大学生心理健康理论与 实践研究一兼评《大学生心理健康教育一体验 - 认知 - 训练》 $[\mathrm{J}]$ 中国高教研究, 2018, 08(1):47.

[10] Zhang Li, Gan Biao. Research on the Professional Construction of Faculty on Mental Health Education of College Students [J]. Chinese Vocational and Technical Education, 2018, (2): 39. 张莉, 甘标.大 学生心理健康教育教师队伍专业化建设状况调查研究[J].中国职 业技术教育，2018，03(2):39. 